\title{
Viajar a España en la primera mitad del siglo XIX: Una aventura lejos de la civilización
}

\author{
JESUSA VEGA* \\ Dpto. de Historia del Arte \\ Universidad Autónoma de Madrid
}

\section{RESUMEN}

El cambio de mentalidad entre el viajero ilustrado y el romántico transformó la experiencia de viajar por España y la imagen que se tenía de ella en el exterior. A la vez, el lento desarrollo del país hizo que se pudieran vivir experiencias imposibles en los lugares de origen de esos viajeros, debido al desarrollo de los medios de comunicación. En este estudio se da una aproximación a la situación de España y la vivencia de ésta por parte de los visitantes foráneos antes de que se establecieran las rutas turísticas como consecuencia del acelerado proceso de modernización que tuvo lugar a partir de mediados de siglo, subrayando los aspectos principales que conllevaba esa aventura de viajar al pasado.

Palabras clave: España, Civilización, Viajero, Comunicación, Tipos, Paisaje.

\section{SUMMARY}

The change in attitude of the romanticist traveller as compared to that of the Enlightenment period transformed both the experience of travelling in Spain and the image of the country abroad. The slow development of Spain at the time made it possible for travellers to live through experiences that were impossible in their own countries. My analysis provides an insight into the Spanish social context and the experiences of foreign travellers before the establishment of touristic routes in the second half of the $19^{\text {th }}$ century, when the modernization process in Spain accelerated. I pay close attention to the main aspects involved in this experience of travelling into the past.

Key words: Spain, Civilization, Traveller, Communication, Stereotypes, Landscape.

\footnotetext{
- No podría haber redactado estas páginas si no hubiera contado en todo momento con la colaboración de Joaquín Álvarez Barrientos, Álvaro Martínez Novillo, Matilde Fernández, Jesús Rubio, Javier Portús, Eva Woods, Ronda Kasl, Jesús Carrillo y especialmente Wade Matthews a cuya generosa amistad debo la posibilidad de que sean leídas. Este estudio se ha desarrollado en el marco del proyecto de investigación "Cultura Visual: La construcción de la memoria y la identidad en la España contemporánea" (BHA 2001-0219).
}

RDTP, LIX, 2 (2004): 93-125 
La Península Ibérica fue desde antiguo destino de peregrinos y no han sido raros los diplomáticos, militares y curiosos que cruzaron los Pirineos durante la época moderna, pero será a partir del último tercio del siglo XVIII cuando el viaje a España despierte un nuevo interés que se transformará en verdadera moda durante el siglo XIX. A lo largo de esta centuria llegaron gentes de países tan distantes como Estados Unidos y Dinamar$\mathrm{ca}$, o tan cercanos como Francia y el Reino Unido. Son muchos los testimonios que se han conservado de las experiencias vividas por los viajeros. Estas fuentes, unidas a la amplia bibliografía que tenemos en la actualidad sobre guías y libros de viajes (Ortas Durand 1999; VV.AA. 1997), y las investigaciones llevadas a cabo en los últimos años sobre el proceso de modernización de España, permiten conocer las razones y acercarse a la manera en la que se viajaba por el país más meridional de Euro$\mathrm{pa}$, allí donde el pasado y oriente estaban hermanados para disfrute del extranjero, ávido de nuevas experiencias.

La primera pregunta que surge es por qué hasta el siglo XIX no se convierte España en un país atractivo para viajar por él. También cabe interrogarse sobre las novedades que se habían introducido en el país para despertar tanto interés entre europeos y norteamericanos, quienes abandonaban el confort para emprender un viaje plagado de restricciones, dificultades y sin sabores. Como escribía Richard Ford, viajar por placer es una invención moderna, pero precisamente los españoles, al no vivir en un país moderno, no conocen ese placer - por otro lado, bastante costoso e inaccesible para la mayor parte de la población, no así para el extranjero-, de manera que lo hacen por necesidad, no para divertirse. En consecuencia, una de las características del país es que no está preparado ni para la acogida del viajero, al cual incluso se mira con recelo, ni tiene desarrolladas las infraestructuras precisas para el viaje. A pesar de todo, durante los dos primeros tercios del siglo el número de viajeros foráneos fue creciente; a mediados de siglo comenzaron a sumarse a esta actividad los nacionales, pero indudablemente serán los primeros los que definitivamente se configurarán como turistas en la segunda mitad de la centuria, cuando viajar por España sea ya viajar por un país más de Europa.

\section{EL VIAJERO ILUSTRADO Y LA IMAGEN DE ESPAÑA}

Para dar respuesta a estas cuestiones y entender el proceso descrito es necesario remontarse a la época anterior. El viaje en el siglo XviI era eminentemente educativo y a España no se venía a aprender, de manera 
que hasta que no cale la idea del viaje como aventura España permanecerá como tierra incógnita ${ }^{1}$. Recordemos que durante el setecientos el viajero europeo veía la realidad bajo el prisma de la civilización - civilizar era el objetivo prioritario de la llustración-, y ello le hacía interesarse sobre todo por los avances y el progreso. Es decir, el visitante foráneo se congratulaba de encontrarse en el país que visitaba como en casa y evaluaba el desarrollo según le resultara más o menos cercano. Civilizar era sinónimo de modernizar y llevaba consigo la idea de urbanizar ${ }^{2}$. El resultado del proceso civilizador tendía a que se igualaran las costumbres y los paisajes, y era propio de las naciones cultas ${ }^{3}$.

El gran reto de la monarquía española durante todo el siglo xviI fue precisamente la modernización, pero el retraso que existía con respecto a otras naciones quedaba a la vista y así se explica el poco interés que ofrecía el país al viajero ilustrado. Esto no significa que España quedara al margen del proceso civilizador (Álvarez Barrientos 2001). Al contrario, el cambio dinástico ocurrido en 1700 dio una nueva orientación en lo relativo a los asuntos de Estado y durante la segunda mitad de la centuria se hizo un verdadero esfuerzo por devolver el prestigio perdido a la monarquía hispana a través del baremo de la civilización. Durante el reinado de Carlos III se privilegió una política de apertura al exterior y sus consecuencias se notan rápidamente en Madrid, ciudad donde está establecida la corte, asimismo Sevilla, Barcelona, Valencia y Cádiz, son núcleos urbanos donde pronto llegaron las novedades y comenzaron a resquebrajarse las formas de vida tradicionales. En ellas se dejaron sentir las modas y los usos importados principalmente de Francia e Italia, pero tam-

1 La asimilación de España como tierra incógnita será una constante y, precisamente, ese es uno de los atractivos que pervivirá hasta bien entrado el siglo xx, ejemplo de ello es el libro del alemán Kurt Hielscher (1921). Habrá enclaves que desde el Renacimiento hasta el siglo xx permanecerán siempre fuera de los circuitos de la civilización, por ejemplo las Batuecas, descubiertas una y otra vez desde Felipe II hasta el cineasta Buñuel (Rodríguez de la Flor 1990).

2 Al sentido que dio Mirabeau a la palabra (dulcificación de las costumbres, inculcación de la urbanidad y la sociabilidad de las gentes) pronto se sumó el de proceso histórico por el que un pueblo sale de la barbarie y alcanza un alto grado de desarrollo (Álvarez Miranda 1992: 387-422). Sobre el proceso civilizador en España véase Deacon (1996: I, 53-72).

3 “La palabra 'civilización' y los hechos sociales y culturales que conlleva se impusieron como forma de historia, como tiempo. Frente a un Antiguo Régimen estático o de ritmo lento en la mayoría de sus valores y formas de vida, la civilización propone aceleración, movimiento, opinión, duda, variedad, debate, todo lo cual cuestiona o altera lo que se entendía como 'genio nacional'. Civilizar era un objetivo de la Ilustración, tanto en España como en otros países” (Álvarez Barrientos 2001: 148). 
bién de Inglaterra y Alemania. En sus calles y en sus formas de sociabilidad urbana - tertulias, salones, cafés, botillerías, tabernas, fondas, mesones, etc.-, se muestra ya el nuevo dinamismo social y económico que trajo a España el progreso, objetivo prioritario de la política de Estado cuyo fin era incorporar a España entre las naciones cultas.

Los españoles ávidos de cambios cruzaron las fronteras para empaparse de cultura y ciencia. Por su lado, los extranjeros comenzaron a mirar a España y, movidos por cuestiones políticas o económicas, se aventuraron a cruzar los Pirineos. Muchos de estos últimos dejaron testimonio de su visión de España y, si bien la mayoría dan fe del esfuerzo que se estaba haciendo por modernizar el país, no ocultan las dificultades —en su opinión, dificultades casi insalvables porque se debían a la idiosincrasia del país, es decir, a sus gentes, su geografía y su historia- y los errores de planteamiento derivados de la inadecuación de los proyectos con la realidad existente, con los recursos. Precisamente la idiosincrasia particular del país se convertirá en uno de los grandes atractivos de España durante el siglo XIX, y esa falta de modernidad será ahora el reclamo que transformará definitivamente el viaje a España en algo muy atractivo porque significará ante todo vivir una aventura hacia el pasado.

No es posible enumerar todas las circunstancias que contribuyeron al fracaso de la política ilustrada, pero hay una fundamental, dado el tema que nos ocupa: los ambiciosos proyectos relacionados con las infraestructuras viarias. Una de las razones principales del retraso en el progreso era el escaso desarrollo y mal estado de los caminos. El medio más adecuado para viajar por España era la mula, y el tipo de vía generalizada por todo el territorio era el camino de herradura. A esta limitación e incomodidad se sumaba la escasez de puentes, que obligaba a grandes rodeos ante obstáculos insalvables y solo permitía viajes estacionales: las nevadas durante el invierno y las lluvias torrenciales en primavera y otoño hacían que muchos pueblos y ciudades, incluida Madrid, quedaran aislados durante periodos más o menos largos. La falta de una infraestructura viaria en condiciones iba acompañada de la escasez de puestos de postas, de pocos, ruinosos y mal atendidos mesones, fondas y hospedajes, y de una inseguridad que hacía que el viajero siempre estuviera expuesto a ser asaltado por bandidos.

La política ilustrada trató de desarrollar un plan general de comunicaciones construyendo, entre otras infraestructuras, los caminos reales; dicho de otro modo carreteras o caminos pavimentados. Seis de ellos eran radiales, comunicarían Madrid con las poblaciones importantes de la costa y con Francia, pasando por los sitios reales, y el resto eran periféricos -los principales fueron los de Barcelona-Valencia, Murcia-Cartagena, Má- 
laga-Antequera, La Coruña-Pontevedra, Oviedo-Mieres y Bilbao-Pancorbo. La pavimentación de los caminos reales comenzó en 1749, pero sólo llegaron a completarse los tramos correspondientes al camino real de Madrid-Andalucía y Madrid-La Coruña -a través de ellos se llegaba a los sitios reales de Aranjuez, El Pardo, El Escorial y La Granja de San Ildefonso-, en los cuatro restantes -Badajoz, Alicante y Francia, por Perpiñán y por Bayona - "tan solo se construyeron algunos tramos, otros fueron mínimamente habilitados y algunos ni recibieron el más mínimo cuidado" (Madrazo Madrazo 1988: 31) ${ }^{4}$. El fracaso se debió, en gran medida, a que el modelo de construcción que se siguió no fue funcional sino que, en el prurito civilizador, se miraba a Francia y se ansiaba tener esos mismos 'paseos señoriales' que tanta fama le habían dado. Esto hizo que se proyectaran caminos de más de nueve metros de anchura, demasiado grandes para la época y demasiado costosos de mantener. A comienzos del siglo XIX apenas se habían alcanzado los lugares de descanso del rey, y se habían construido algunos trechos en torno a los puertos marítimos, pero para entonces había ya partes que se encontraban en mal estado ante la falta de recursos para su conservación. Si a estas circunstancias unimos el desorden general y la destrucción material que trajo la guerra contra Napoleón es fácil adivinar la dificultad y el reto que significaba planear un viaje por España en el primer tercio del siglo XIX, y a la vez la aventura que suponía emprenderlo: el viaje era difícil y complejo de programar por el clima; la comida, poco apetecible, se conseguía con dificultad; los caminos eran malos y las posadas peores sin las más mínimas comodidades, etc. En una palabra, no había infraestructura.

Hay que tener también en cuenta la idiosincrasia del país para entender el poco atractivo de España para el viajero ilustrado. Entre los extranjeros que se aventuraron a cruzar los Pirineos en las últimas décadas del siglo XVIII se aprecia un número creciente de aquellos que decidieron publicar sus experiencias. Poco contribuyeron con ellas a cambiar la imagen y la fama que tenían los españoles. La fama o si se quiere la mala fama de España y los españoles venía de atrás: se remontaba al comienzo de la época moderna y con ella se justificaba plenamente no viajar a un país holgazán, atrasado, fanático y supersticioso que no había aportado nada al proceso civilizador y a la historia ${ }^{5}$. Es más, los ilustrados es-

\footnotetext{
${ }^{4}$ Alexander Jardine (1788), en la cuarta carta de la serie que escribió desde España entre 1778 y 1779 comenta que todavía no se había emprendido el camino que iba de la frontera con Francia a Burgos.

${ }^{5}$ En 1752 Lord Chesterfield escribía a Lord Hundington lo siguiente: "España es seguramente el único país de Europa que ha caído más y más en la barbarie, en la misma proporción en la que otros países se han ido civilizando" (Freixa 1993: 23).
} 
pañoles fueron conscientes como nunca de esta realidad y muchos de sus esfuerzos se dirigieron precisamente a contrarrestar esa opinión. Un caso paradigmático fue el Viaje de España de Antonio Ponz ${ }^{6}$, que tanta utilidad tendría para el viajero extranjero, cuyo objetivo principal era recoger todo lo bueno que en materia de ciencias y artes había dado España, y dar noticia de los proyectos y novedades que se iban introduciendo como consecuencia del proceso civilizador. Estas circunstancias explican el tono relativamente optimista, positivo y de propaganda que le dio el autor, y que no escapó a algunos de los pocos viajeros extranjeros ilustrados que se sirvieron de él como cicerone.

Por lo expuesto es fácil comprender que España quedara fuera del "grand tour", pero esta misma circunstancia llevó a un desconocimiento europeo casi total y a que la imagen que se tenía del país se quedara anquilosada, fosilizada, la de un país pobre y en continua decadencia. Esa imagen se había construido a través de la historia política y la progresiva pérdida de esplendor de la dinastía de los Habsburgo. La llegada de los Borbones no trajo sustanciales novedades, y España se convirtió, a los ojos de los europeos más benévolos, en un apéndice provinciano, sin interés, de la corona francesa. Desde luego iba a ser muy difícil sacudirse el lastre de esa imagen porque, para reafirmarla, existía una rica producción literaria y visual que no era posible obviar. Entre las fuentes literarias lo primero que hay que tener en cuenta es la producción de los propios españoles: los romances, la novela picaresca traducida desde temprano a otras lenguas - siendo El lazarillo de Tormes la obra por excelencia-, además de obras como La Celestina de Fernando de Rojas, El Buscón de Quevedo y, cómo no, El Quijote de Cervantes (en opinión de Richard Ford era buena guía y ejemplo para el viajero moderno, razón por la que debía formar parte de su equipaje). A esta literatura se fue sumando la producción extranjera referida tanto a la historia de España - la visión coetánea más negativa que cabía dar la escribió Nicolás Masson de Movilliers en 1782 en el tomo dedicado a la Geografía de la Enciclopédie Methodique 7como a la ficción sobre el país: recuérdense los populares libros de Alain-

\footnotetext{
${ }^{6}$ Consta de dieciocho tomos, publicados en Madrid entre 1778 y 1794 . Van seguidos de dos tomos titulados Viaje fuera de España. En estos últimos Ponz no puede menos de tener presente el trato que se ha dado a los españoles quejándose, no sin amargura, en estos términos: "Es conveniente que los nacionales y extranjeros se desengañen del indigno modo con que nos tratan ciertos escritores, se deben repetir sus calumnias e injusticias, publicarlas e impugnarlas muy a menudo, y dar, de este modo, a conocer la mala fe y modo que han tenido de tratarnos" (Ponz 1947: 1667).

7 A mediados de la década de 1770 la ofensiva crítica foránea se radicalizó y en su conjunto provocó una reacción de protesta en el país (Mestre 1983; Álvarez Barrientos 2001; García Cárcel 2003: 207-213).
} 
René Lesage, Le diable boiteux, basado en el original del español Luis Vélez de Guevara, y Gil Blas. Finalmente, en los últimos años del siglo xviII se publicaron obras señeras sobre España escritas por viajeros que consolidaban esa imagen, si bien hubo autores más benévolos como Henry Swinburne (1779).

En el siglo xviII esta imagen pícara y truculenta de España y los españoles no tenía atractivo. En 1783 el editor de una colección de viajes, John Fielding, escribía: "Nada excepto la necesidad puede inducir a alguien a viajar por España: debe ser idiota si hace el 'tour' de este país por mera curiosidad, a menos que pretenda publicar las memorias de la extravagancia de la naturaleza humana. En este caso, no puede hacer mejor, porque en todos sitios encontrará orgullo, bajeza, pobreza, ignorancia, fanatismo, superstición y ridículas ceremonias" (Feixa 1993: 24). En conclusión, como reconocía Christian August Fischer (1799), venir a España era un viaje al fin del mundo, de hecho en ella existía un lugar llamado Finisterre, cuando no era irse al otro mundo ${ }^{8}$.

Esta visión era la que también se transmitía por medio de las imágenes. Sobre las fuentes visuales de origen español cabe decir que siempre fueron escasas debido, a pesar de los esfuerzos, a la carencia de grabadores españoles que difundieran, a través de las estampas, los monumentos y una visión positiva de las costumbres del país (Carrete 1989; Bozal 1989). No obstante, hay que recordar el éxito de la pintura de Murillo, tanto dentro como fuera de España, especialmente sus cuadros de niños y vida cotidiana durante el siglo XIX (García Felguera 2001) ${ }^{9}$, que venían a reforzar esa imagen literaria. Fue a través de las estampas extranjeras como se dio a conocer España. Entre las colecciones más importantes hay que citar las de Louis Meunier (1665), Pieter van de Berge (1701), y las que acompañaban la obra de Jean-François Bourgoing (1788). Mención aparte merecen los escritos de Juan Álvarez de Colmenar, y entre ellos Les delices (Álvarez de Colmenar 1707) ilustradas con estampas por dibujos del autor, realizados en los escenarios naturales. Entre éstas se encontraban cuatro referidas al Santo Oficio, es decir a la Inquisición, que sin duda espantarían al lector/espectador: además del "Auto de fe", se mostraban las torturas que sufrían los acusados. Todas estas imágenes fueron

${ }^{8}$ El 20 de octubre de 1838 el marqués de Astolphe de Custine escribía a una amiga comunicándole que Chopin se iba "a Valencia de España, es decir, al otro mundo" (Planas 2000: 14).

9 Richard Ford se hace incluso eco de la historia de que Murillo hacía el color siena con pedazos de pucheros machacados para explicar el color tostado que caracterizaba a las salsas en la comida española. 
copiadas una y otra vez y, sobre todo a lo largo del siglo xviII, sirvieron de base para los cosmoramas de grandes perspectivas y amplios colores que tanto entretuvieron a los burgueses europeos. Esa visión bastante distorsionada, cuando no inventada de España, comenzó a cambiar con la magna empresa del Voyage pittoresque llevada a cabo por AlexanderLouis-Joseph Laborde (1806-1820). Aunque la obra es claramente fruto de una mentalidad ilustrada y tiene carácter enciclopédico, es de destacar que se organizó siguiendo itinerarios y que el propósito del autor, según se lee en la introducción, era descubrir a los franceses un país al que era llegado el momento de conocer: "España, desde hace tanto tiempo extraña a nuestros intereses políticos, a nuestras relaciones comerciales, incluso a nuestra curiosidad, va a dejar de serlo bajo todos estos aspectos, cuando forme parte del mismo sistema y adopte las costumbres europeas y los viajes sean en ella menos penosos" (Pardo 1989: 28) ${ }^{10}$.

\section{EL VIAJERO ROMÁNTICO ANTE EL MITO RENOVADO DE ESPAÑA}

Literaria y visualmente el mito de España se consolidó antes del siglo xIx. Se basaba en el contraste, en esa mezcla agridulce de la que habla Jean-Claude Berchet en su introducción al Voyage en Espagne de Théophile Gautier (1981: 16): "gravedad/alegría; indolencia/energía; honor/sensualidad; violencia/gentileza; Castilla/Andalucía; Don Quijote/Sancho Panza, etc. Esta estructura fundamental de la visión integra desordenadamente un conjunto de toques coloristas, más o menos pintorescos: danzas, trajes, corridas, guitarra, gitanos, cigarros..." A comienzos del siglo XIX el mito comenzaba a desvanecerse y un ejemplo es el libro de Laborde, el cual se ilustró con un elevado número de estampas que daban una imagen renovada de España. No obstante su vigencia fue breve porque, si bien es cierto que servirá de referente, una vez confinado Napoléon en Elba y restablecido el orden en Europa, el viajero que cruce los Pirineos tendrá un nuevo concepto del viaje resultando indiferente que España hubiera cambiado o no. Lo que pasó fue que aquello que repudiaba el hombre ilustrado se tornó en atractivo para el romántico, máxime cuando realidad y literatura parecían poner de manifiesto que el factor fundamental de la

\footnotetext{
${ }^{10}$ Dadas las circunstancias políticas y el tipo de obra profusamente ilustrada, la publicación completa que vio la luz en París se dilató mucho en el tiempo, de 1807 a 1818. La imagen que da de España es muy positiva pero no hay que olvidar que contó con el patrocinio de Carlos IV y, de hecho, comenzó a publicarse en español (Laborde 1807).
} 
cultura española eran la diversidad y lo popular ${ }^{11}$, algo que precisamente será también buscado con avidez durante ese siglo, cuya revolución industrial estaba arrasando la cultura tradicional.

La experiencia de estos nuevos viajeros, así como el relato de la misma, condicionará una adaptación de la visión del país a la mentalidad romántica. Esta visión romántica provocará nuevas distorsiones y falseamientos que, al contrario de lo que ocurrió en siglos anteriores, lejos de disuadir al viajero, se convertirán en el mejor reclamo para que en el curso del siglo XIX sea creciente el número de extranjeros y gracias a ellos comenzará la organización de la visita turística. Lo expuesto no significa que no se supiera que la paradigmáticamente romántica Espana tenía mucho de construcción visual. Por ejemplo, en Inglaterra, lugar de procedencia de muchos de los viajeros, el famoso Blanco White no dejó de denunciar la falsedad que había en los dibujos de David Roberts que gozaban de gran aceptación:

\begin{abstract}
Como obras de arte son admirables, pero también son bellezas infieles. Los detalles arquitectónicos de cada edificio están representados con exactitud [...] el artista se ha servido de sus apuntes según los dictados de su fantasía, agrupándolos sin ningún respeto a la verdad. Y lo que me resulta más odioso es la parte animada de estos grabados, sus figuras, que para mí son - como el castellano chapurreado-, falsas, incongruentes, exageradas. Como cree que los monjes son más pintorescos que el clero diocesano, llena las catedrales de esas absurdas figuras de frailes ${ }^{12}$ ¿Les gustaría a los ingleses que alguien hiciese vistas de Londres con la gente disfrazada y como caricaturizada? Pero esto pasa con casi todo lo que sale aquí al mercado. Lo mismo ocurre con los libros de viajes, salvo pocas, poquísimas excepciones ${ }^{13}$.
\end{abstract}

Se puede afirmar que la manipulación visual de la España real fue una constante, incluso con el desarrollo de la fotografía ${ }^{14}$, pero ésta era una cuestión que no preocupaba, es más, algunos editores sin escrúpulos

${ }^{11}$ El viajero ilustrado tomó conciencia de esa diversidad pero rara vez llegó a convertirse en uno de los temas principales del relato (Pino y Romero de Tejada 1996).

${ }^{12}$ Sobre el viaje a España de David Roberts y su interpretación artística cfr. Giménez Cruz 2004.

${ }^{13}$ The Life of the Rev. Blanco White, written by bimself, II, p. 314 (Alberich 1976: 31). La producción visual fue ingente (VV. AA. 1981).

${ }^{14}$ Un ejemplo es la sesión fotográfica que organizó Clifford entre el 10 y el 13 de octubre de 1862 en Granada con motivo del viaje oficial de la reina Isabel II: contrató a una familia de gitanos y la hizo posar en el Patio de los Leones de la Alhambra (Fontanella y Kurz 1996: 135). Evidentemente todo esto se hizo con el beneplácito de la reina, ya que el destino era el álbum fotográfico oficial de las jornadas reales. Testigo de los hechos fue Christian Andersen (Andersen 1988: 129). 
falsearon por completo la información visual. Un caso extremo puede ser la edición londinense, en 1864 , de Richard Bentley sobre la famosa obra de Hans Christiana Andersen, In Spain. Las pocas estampas que adornan la edición llaman la atención: en el capítulo de Sevilla en lugar de una vista de la ciudad encontramos otra ciudad que nada tiene que ver, probablemente se trata de una vista de Bolonia; Córdoba se muestra a través de una imagen de alguna ciudad rusa o polaca; la vista de las calles de Toledo es probablemente de una ciudad alemana....; finalmente en Barcelona se podría visitar un monumento árabe en cuyo interior hay un patio que recuerda el de Los leones de la Alhambra ${ }^{15}$.

Al contrario de lo que ocurriera con los ilustrados, estas circunstancias lejos de espantar a los visitantes los atraían. España, durante una buena parte del siglo XIX, fue uno de los países más atractivos de Europa. No obstante, para entender esta transformación, también hay que tener en cuenta otras circunstancias históricas. La Revolución Francesa y las guerras napoleónicas frenaron a los espíritus viajeros, pusieron fin a la práctica del "grand tour" y, lo que es más importante, supusieron un cambio de actitud hacia los españoles y dieron a España un nuevo lugar en el concierto europeo. Se conservan bastantes relatos de gentes, en su mayoría de militares franceses e ingleses, que participaron o vivieron en España durante la guerra contra Napoleón. Sus escritos no abundan en noticias sobre el país y sus costumbres, asuntos que precisamente serán los que atraerán al viajero romántico, sino que, por el contrario, se centran en cuestiones tácticas o descripciones de las campañas militares. No obstante, en algunos queda reflejo claro de la devastación que supuso la contienda - vastas regiones desoladas y asoladas por tres ejércitos depredadores que agravaron la situación previa de despoblamiento del país-, y la gesta de los habitantes contra el coloso francés. La difusión de este tipo de literatura comenzó a atraer las miradas sobre los españoles por su valor y tenacidad en la lucha. Edward Hawke Locker (1824), miembro de la armada británica bajo el mando del Duque de Wellington, en la Introducción de su libro escribía:

\footnotetext{
${ }^{15}$ Ciertamente el editor se dejó llevar por el texto: "Al salir a una placita, oí sonar una trompeta; la gente comenzó a agolparse en torno a unos titiriteros que, vestidos de tricot y abigarrados pantalones de paño, y con pleno convencimiento de ser artistas nacidos para actuar bajo techo y no en la calle, extendieron una gran alfombra sobre el empedrado, para allí demostrarnos su arte. Un pequeño de ojos negros, un mignon de tierra hispana, bailó y tocó la pandereta y se dejó volver del revés y hacer nudos por su semidesnudo papá. Para verlo mejor subí un par de escalones que había en la entrada de un viejo patio con una única ventana de ajimez, grande, de estilo moruno; su doble arco de herradura caía sobre esbeltas columnas de mármol" (Andersen 1988: 23).
} 
Hemos cometido con ellos [se refiere a los españoles] una gran injusticia, al identificar el carácter del pueblo con los errores de sus gobernantes. Los españoles constituyen una raza tan loable como cualquier otra en el mundo. Hay valor, integridad, generosidad en su carácter, que se muestra de manera notable en la hombría de su aspecto exterior.

Otra circunstancia que hay que tener muy presente para entender el nuevo interés que despertó España es el profundo cambio que tiene lugar en la mentalidad del viajero. En él hay un afán por conocer la realidad inmediata y los vestigios del pasado: "el viajero romántico no buscaba sólo conocer el mundo exterior, sino conocerse a sí mismo. Y cuando se dirige al mundo exterior lo hace interesado tanto en su superficie como en su historia, tanto a su estado presente como a la reconstrucción del pasado que lo explica. Busca su alma y su esencia" (Rubio 1992: 24). En la abundante y creciente literatura de viajes que produce España en los años centrales del siglo, se ve claro el deseo de dejar constancia de la experiencia vivida, de transmitir las sensaciones que produce la contemplación de una realidad que permite dejar volar la imaginación. El viajero en España construirá o reconstruirá a su medida la historia y tendrá la capacidad incluso de visualizar el pasado - histórico o inventado-, y lo hará de manera tan real que cuando lo escriba se persuadirá a sí mismo y a sus lectores de su vigencia. Un ejemplo paradigmático, y realmente trascendente para el turismo futuro, sería la visita a Granada en 1828 de Washington Irving, cuyo resultado inmediato fueron Los cuentos de la Albambra, y, a la larga, la fascinación general por el palacio encantado (Requejo 1990) ${ }^{16}$.

Evidentemente había contrastes entre la imaginación y la realidad pero en ocasiones la experiencia de volver a la realidad no parece que fuera traumática. Un ejemplo singular lo tenemos en Christian Andersen cuando relata su estancia en Valencia:

Todavía existe en la vetusta muralla de piedra, de almenada cresta, el pórtico por el que entró el cadáver a caballo aquella noche de angustia y de muerte para los sarracenos. Me cobijé a la sombra de dicho pórtico y me puse a pensar en el héroe y en su caballo; y, justo en ese instante, apareció un rapaz retozón y jubi-

${ }^{16}$ El 8 de octubre de 1830 Merimée (1988: 32) escribía a Sophie Duvaucel en estos términos: "No le diré nada sobre la Alhambra: la tiene usted en su biblioteca; pero créame que no está dispensada de hacer el viaje a Granada y que ningún libro en cuarto, ni siquiera en folio, podrá darle una idea del Patio de los Leones y del Salón de Embajadores". Desde luego la capacidad evocadora e inspiradora de las ruinas dejó magníficos relatos en otros autores, recuérdese, por ejemplo, la visión del pasado inquisitorial en la obra de George Sand ante los escombros del convento en ruinas de Santo Domingo. 
loso a la grupa del penco más miserable que había visto en mi vida, pellejo y huesos, el símbolo del hambre entre todos los cuadrúpedos; y mi pensamiento trascendió del noble caballero de $\mathrm{El} \mathrm{Cid} \mathrm{al} \mathrm{de} \mathrm{don} \mathrm{Quijote,} \mathrm{ambos} \mathrm{igualmente}$ inmortales en el mundo de los romances; dos polos opuestos; Babieca y Rocinante (Andersen 1988: 48).

Por otro lado, la poética de las ruinas - tan programática en el pensamiento de Chateaubriand-, encontrará en España un ambiente idóneo para sentirla y desarrollarla, y un escenario adecuado para la leyenda. El paso del tiempo había hecho su labor y eran muchos los monumentos que en su ruina se habían fundido en armonía con la naturaleza: "Las montañas poco elevadas del reino de Valencia se ven coronadas, con frecuencia, de castillos en ruinas", escribía en 1830 Merimée (1988: 99). Además, la valerosa contienda contra Napoleón había plagado prácticamente todo el país de cicatrices heroicas - hasta en las paredes del Museo del Prado, visita obligada para cualquier viajero que se preciara (Portús 1994) se encontraban recuerdos de ella (Merimée 1988: 109)- y las ciudades que sucumbieron gloriosamente tras penosos asedios, como Zaragoza, despertaron emociones desde un principio: en el momento de los hechos, Vaughan (1809) fue capaz de ver la hermosura de la ciudad entre las ruinas y la devastación, y diez años más tarde, en 1818, Ticknor (1913:22) no pudo menos que admirar el heroísmo de la resistencia zaragozana a través del escenario de sus "impresionantes ruinas (awful ruins)" (Ortas Durand: 93).

También hay que tener en cuenta las ambientaciones medievales que tanto gustarán a los románticos —desde Walter Scott hasta Víctor Hugo o Balzac-, e igualmente encontraban en España múltiples escenarios naturales donde dar rienda suelta a la imaginación: muchas de las ciudades seguían conservando los recintos amurallados y el caserío era tan antiguo que resultaba fácil asimilarlo a épocas pasadas, incluso tan lejanas como el Medioevo; por otro lado, muchos caminos eran practicables gracias precisamente a los puentes romanos y medievales (VV. AA. 1987) ${ }^{17}$. Es más, el viajero podía literalmente vivir en el pasado la existencia cotidiana, remontarse a épocas tan pretéritas como la romana - la manera de trabajar el campo, el trato a los criados o las posadas eran, en opinión de los viajeros, los mismos o muy semejantes a los que se emplearon en la Antigüedad-, o a momentos más cercanos, pero no por ello menos

\footnotetext{
${ }^{17}$ Nada más entrar en España, Christian Andersen (1988: 13) escribe: "Restalló el látigo: salimos corriendo por vueltas y revueltas de angostas calles; pasamos raudos sobre puentes almenados y a través de fortalezas, muy propios como decorado de una escena de teatro medieval".
} 
desaparecidos, como la manera de viajar: el consejo que da Ford a sus lectores es el mismo que dio Fines Moryson a los que viajaban por Inglaterra hacía dos siglos, abandonar las carreteras e introducirse por los caminos de herradura, para hacer un viaje en el tiempo. No hay que olvidar, además, la presencia de la religión y el clero católico en la vida cotidiana española —el papismo tenía, para los viajeros procedentes de países que abrazaron la Reforma un claro sabor medieval, debido a la pervivencia de los ritos y los hábitos devocionales-, y todos sentían, apenas llegaban a tierra española, la presencia de la Inquisición, a pesar de que hubiera desaparecido. Por último, el lento proceso de urbanización hacía que las formas de vida del medio rural se encontraran a las puertas mismas de las ciudades, incluida Madrid, la capital, y en ellas, debido a la emigración campo-ciudad que será creciente según avance el siglo, habrá una gran diversidad que también resultará atractiva al extranjero.

\section{TIPOS POPULARES: COLORIDO Y DIVERSIDAD}

El pueblo español será uno de los grandes atractivos y de los grandes tópicos del viajero: la imagen de España se configurará en la primera mitad del siglo XIX, y convertida ya en estereotipo prácticamente a mediados del mismo, es decir, castañuela, mantilla y flamenco ${ }^{18}$, será al final de la centuria la seña de identidad para el exterior. Si nos remontamos a la percepción que tenía el viajero del último tercio del siglo xviI se ve que, a pesar de ser conscientes de la diversidad cultural de España, se tendía a caracterizar a los españoles en su conjunto y, normalmente, por oposición al francés. Entre los viajeros del siglo XIX, por el contrario, se subrayará la diversidad regional y el contraste que existía en la población, comprensible, a ojos del extranjero, por ser expresión de la variedad geográfica del país:

La lengua, trajes, costumbres y carácter local de los habitantes son tan varios como el clima y la producción del suelo. Las cadenas de montañas que atraviesan toda

${ }^{18}$ En noviembre de 1846 se encontraba en Barcelona Merimée (1988: 185-6) donde escribe: "Heme aquí llegado al término de mi largo viaje sin haberme encontrado con trabucaires ni ríos desbordados, lo que es todavía más raro [...] Pero no estoy en España y seguramente a mil leguas de Andalucía, aunque haya en esta tierra gitanos y guitarras. Encuentro a los catalanes como franceses ruines, un poco toscos y con grandes deseos de ganar dinero". En otra carta dice: "Heme aquí desde hace ocho días en esta sucia ciudad que afecta aires de capital, y que se parece como dos gotas de agua a la capital de un departamento industrial, española únicamente por el hecho de que la gente del pueblo se cubre con harapos rojos y calza zapatos de cuerdas" (1988: 190). 
la Península y los profundos ríos que separan algunas partes de ella han contribuido durante muchos años, como si fuesen murallas y fosos, a cortar la comunicación y a fomentar la tendencia al aislamiento

escribe Richard Ford (1974: 13) casi al comienzo de sus Gatherings from Spain (1846). El autor logra una síntesis excelente entre los reinos históricos, el medio natural y las gentes que lo habitan - laboriosos catalanes, adustos castellanos, risueños valencianos, desconfiados murcianos, alegres y desenfadados andaluces, etc.- . La variedad regional se apreciaba claramente por el atuendo de las gentes, con el cual podía el viajero gozar plenamente no sólo de lo antiguo, sino también de lo exótico: según su visión, pervivía la herencia árabe en muchas maneras de vestir ${ }^{19}$. Lo mismo ocurría en las formas de vivir: compartir el colchón, tomar la comida del mismo plato o sartén, o beber del mismo vaso era bastante común en los alojamientos que encontraba el viajero ${ }^{20}$. También era habitual, como advertía Henry Davis Inglis (1831), ver en los barrios humildes y en los talleres artesanos a las gentes sentadas sobre esteras y en cuclillas, y la costumbre, entre los niveles más elevados de la sociedad, de emplear asientos, taburetes y banquillos bajos, era vista como herencia de los siglos de dominación musulmana ${ }^{21}$.

Todavía más interesante era hablar con los españoles. Esto compensaría de los sacrificios ${ }^{22}$, ya que muchos de los momentos placenteros del

${ }^{19}$ La descripción de los trajes es una constante en los viajeros, con verdadero deleite se detiene en ellos Charles Davillier porque allí es donde se encuentra la verdadera España, no la España de "opereta y de los keepsakes" (Davillier 1984: 11). Los trajes tradicionales ya estaban amenazados de desaparición cuando, junto a Doré, hizo su viaje por España muy a principios de la década de 1870 . Sobre la pérdida y recuperación del traje, Vega (2002: 17-68).

${ }^{20}$ No sin repugnancia narra su experiencia Merimée (1988: 35). Recuérdese que según avanza la civilización así lo hace la intimidad, en consecuencia en los alojamientos que había disponibles para el viajero ésta, en muchas ocasiones, brilla por su ausencia.

${ }^{21}$ La costumbre de "sentarse a la morisca" siempre despertó gran curiosidad entre los extranjeros, no obstante era propia sólo de mujeres. Casanova (1982: t. v, 130) dejó un elocuente testimonio: "Doña Ignacia, cortés, se levantó del suelo, donde estaba sentada con las piernas cruzadas, como las africanas: costumbre de los moros que todavía permanece. He visto en Madrid a mujeres de buena cuna sentarse de esta forma sobre el entarimado [el estrado], y sobre todo en las antecámaras de la Corte y en la del palacio de la princesa de Asturias. Las españolas se sientan sobre las piernas en las iglesias, donde no hay ni bancos ni sillas; tienen una agilidad sorprendente para pasar de esta posición a posternarse de rodillas, o a levantarse, y viceversa". Pervivía aún esta costumbre en algunos lugares apartados, al comenzar el siglo xx.

${ }^{22}$ Esta recomendación se puede leer ya en los viajeros del siglo xviII. Alexander Jardine (2001: 205) en la Carta VII hace el siguiente comentario al respecto: "Aquellos 
viaje vendrían de la conversación con los paisanos. Para ello era preciso conocer el idioma ${ }^{23}$, o bien contratar un buen criado que lo hablase perfectamente para que hiciera de intérprete, o servirse de un guía. Fue creciente el número de éstos últimos según avanzaba el siglo XIx. Se ofrecían al viajero según llegaba a la ciudad. Con el tiempo, algunos gozaron de buenas credenciales: por ejemplo, William George Clark en Gazpacho; or Summer Months in Spain, cuenta cómo nada más llegar a Granada se lo disputaron, para acompañarle, Mateo Jiménez - guía descrito por Washington Irving - , su hijo del mismo nombre, y un judío oriundo de Gibraltar, recomendado por Richard Ford en su Handbook (Alberich 1976: $40)^{24}$. En fin, un buen criado podía enriquecer el fruto del viaje y llegar, incluso, a transformarlo en interesante ${ }^{25}$. No es aventurarse mucho generalizar y afirmar que existía la tendencia entre los amos a ver en su criado un Sancho Panza redivivo, así se tenía una sensación más real de la aventura de recorrer España; por lo demás, no cabe duda que los criados procuraban hacerlos creer que procedían del mismo tronco que Sancho -Ford, al tratar de ellos, llega a decir que sus defectos son de raza-, es decir, que prácticamente eran sus descendientes. En definitiva, el guía se sumó al repertorio de "tipos característicos" del país que tanto entretenían y atraían al viajero.

Algunos tipos estaban asociados a los oficios y, como ocurriera con otros aspectos de la realidad, el atraso en la civilización hacía que conser-

que deseen conocer España y a los españoles deben antes residir entre ellos para aprender el idioma y, más tarde, recorrer el país y quedarse algún tiempo en los distintos lugares que pueden destacarse. Conocerlo bien exigirá tantas penas y fatigas como en muchos países más desarrollados. Debe estar preparado para soportar muchas incomodidades, la suciedad, la escasez, los bichos, etc., pero ya ha oído hablar bastante de estas cosas, puesto que a veces nuestros compatriotas melindrosos las exageran, y es probable que esté prevenido contra lo peor. Sin el manejo del idioma, no puede esperar más que un conocimiento limitado de este pueblo, y una satisfacción aún menor. Su conversación será la responsable de sus ratos más placenteros, y es muy superior de lo que cabría esperar de un pueblo tan aislado y en unas condiciones como las actuales".

${ }^{23}$ Probablemente el viajero más célebre y que más sufrió por el idioma fue Andersen (1988: 248-250).

${ }^{24}$ Contrató los servicios de Mateo, quien le asombra con su audacia y sus confusiones, aunque siempre apelaba a la reconocida autoridad de "Vasindon Eerveen".

25 "Las antigüedades, sobre todo las antigüedades romanas, me impresionan poco —escribía Merimée (1988: 95-6) en 1830-. No sé como me dejé convencer para ir a Murviedro a ver lo que queda de Sagunto [...] Sin embargo, mi excursión a Murviedro no me aburrió. Contraté un caballo y un campesino valenciano para que me acompañara a pie. Le encontré muy charlatán, medianamente bribón pero, en resumidas cuentas, buen compañero y bastante divertido". 
varan en el presente comportamientos y costumbres de épocas pasadas ${ }^{26}$. Además, según Borrow, que recorrió el país de norte a sur y de este a oeste, no sólo no era necesario buscar mucho para toparse con tipos interesantes, sino que había posibilidad también de encontrar a una parte representativa de ellos en la misma capital ${ }^{27}$. En Madrid, salvo un "puñado de extranjeros, principalmente sastres, guanteros y perruquiers franceses", la población era "estrictamente española" y no madrileña porque una buena parte de ella no era oriunda de la ciudad, ni siquiera de la región. $\mathrm{El}$ autor hace una ingeniosa glosa sobre ellos:

¡Salud aguadores de Asturias, que, con vuestro grosero vestido de muletón y vuestras monteras de piel, os sentáis por centenares al lado de las fuentes, sobre las cubas vacías o tambaleándoos bajo su peso, una vez llenas, subís hasta los últimos pisos de las casas más altas! ¡Salud caleseros de Valencia, que, recostados perezosamente en vuestros carruajes, picáis tabaco para liar un cigarro de papel, en espera de parroquianos! ¡Salud, mendigos de la Mancha, hombres y mujeres que, embozados en burdas mantas, imploráis la caridad indistintamente a las puertas de los palacios o de las cárceles! ¡Salud, criados montañeses, mayordomos y secretarios de Vizcaya, y Guipúzcoa, toreros de Andalucía, reposteros de Galicia, tenderos de Cataluña! ¡Salud, castellanos, extremeños y aragoneses, de cualquier oficio que seáis! y, en fin, vosotros, los veinte mil manolos de Madrid hijos genuinos de la capital, hez de la villa, que con vuestras terribles navajas causasteis tal estrago en las huestes de Murat el día Dos de Mayo (Borrow 1996: 162) ${ }^{28}$.

26 "En Barcelona, como en otras ciudades españolas, persiste la organización medieval que permite a los diferentes gremios establecerse en calles propias" (Andersen 1988: 24).

${ }^{27}$ El 16 de octubre de 1853 escribía Merimée (1988: 231) desde Carabanchel: "Cuando voy a Madrid, voy a hacer estudios de costumbres entre la baja sociedad. Sería incapaz de creer, señora, cuán amable es la gente del pueblo en este país, cuánto ingenio, dignidad y grandeza de alma se encuentra en lugares en que nunca imaginaríamos encontrarlos". El 31 del mismo mes desde Madrid en otra carta decía: "Créame que lo más curioso y digno de la atención del viajero, sobre todo en este país, son los estudios de costumbres" (Merimée 1988: 242).

${ }^{28}$ Hubo desde luego muchos viajeros que vista Madrid, consideraban vista España pero hay que tener presente que, por lo menos, la ciudad ofrecía la diversidad y el atraso dentro de un cierto confort al que, evidentemente, muchos no estaban dispuestos a renunciar. Recorrer la Península no era apto para señoras elegantes o caballeros delicados. En la berlina en la que hacía uno de sus viajes de regreso a Francia Merimée (1988: 140) en octubre de 1840 viajaban "dos ingleses - hombre y mujersuperlativamente feos y tontos ambos. Han pasado diez días en la calle de la Montera y se van con una opinión inamovible sobre España". Por lo demás dentro del país había también niveles distintos, el mismo autor en un momento de ese viaje escribe: "entre Burgos y Vitoria hay al menos cuatrocientos años de civilización. Buena posada, limpia y llena de mozas con rostros agradables, que no cesan de cantar o reír" (Merimée 1988: 142). 
Todo el interés que despertaba el pueblo, en el cual percibía el foráneo claramente la herencia oriental, se tornaba en aburrimiento, indiferencia y sentimiento de superioridad hacia una nobleza, una aristocracia y una incipiente burguesía que torpe, y a veces ridículamente, emulaba las modas y hábitos de la sociedad parisina. No cabe duda de que la fama de ignorantes, ociosos, superficiales y vanidosos que arrastraban los primeros desde tiempos pretéritos hicieron mella en los extranjeros ${ }^{29}$, pero la razón principal del desinterés radicaba en que apenas existía diferencia - salvo la de un relativo retraso que se tornaba en ridículo a ojos del viajero- entre ellos y sus correspondientes del resto de Europa. En cuanto a la incipiente burguesía su tendencia era, siempre que hubiera posibilidad, adoptar y emular las costumbres sociales de la aristocracia, razón por la cual tampoco atraía la atención.

Las conversaciones y experiencias más interesantes se tenían con el pueblo llano, pero dentro de él había unos tipos característicos, españoles por antonomasia y estrechamente relacionados entre sí, con los que cualquier viajero quería entrar en contacto como fuera: el torero, la "Carmen" y el bandolero. Como explica Álvaro Martínez Novillo, fue a lo largo del el siglo XviII cuando se configuró, en medio de un gran entusiasmo popular, la moderna tauromaquia - la que pervive en la actualidaden la que la parte fundamental es la faena realizada por los toreros a pie, cuya procedencia social era popular, y no la nobleza como había ocurrido en tiempos anteriores. En palabras del historiador, "la corrida de toros como espectáculo alcanzó su primer momento de esplendor, una verdadera edad de oro, en el último tercio del siglo xviII, cuando unos toreros de excepcional personalidad hacen que su inspiración, destreza y arte les faculten para enfrentarse, siguiendo unas reglas establecidas, a unos animales de gran bravura" (Martínez Novillo 2002: 137). Es conocida la animadversión del pensamiento ilustrado hacia este tipo de espectáculos y los esfuerzos de los ilustrados españoles en concreto para que fueran prohibidos. No obstante, la visión de los toros entre los extranjeros no era completamente negativa, valga recordar que Jean Jacobo Rousseau opinaba que precisamente las corridas de toros habían contribuido en gran medida "a mantener un cierto vigor" en la decadente nación española. Es

${ }^{29}$ Recuérdese que en 1795 William Beckford se refería en estos términos al hablar de los nobles españoles: "Si la raza de los grandes de España pudiera por cruzamientos bien estudiados mantenerse igual de bien [que los caballos y las vacas], España no tendría que lamentar la vil y ruin generación actual de su nobleza. Si siguen degenerando mucho tiempo más y acumulando tierras y enfermedades gracias a los matrimonios consanguíneos me temo que estarán andando a cuatro patas antes de que el siglo que viene esté muy avanzado" (Pardo 1966: 153). 
muy posible que esta visión fuera también consecuencia de la profunda transformación que se vivió en el mundo del toreo, porque "lo que fue casi un mero espectáculo circense hasta mediados de siglo, en torno a 1775 ya se había convertido en un verdadero arte, lleno de emoción en el que el espada, tras seguir unos tiempos prescritos en una organización cuasi-neoclásica (faena de capa, suerte de varas, banderillas y faena de muleta) mataba al toro de frente con la sola ayuda de un trozo de paño y un estoque". Tanto los espadas como los principales subalternos adquirieron verdadera perfección en cada uno de los tiempos del espectáculo, esto, unido a la personalidad de algunas figuras en las últimas décadas del siglo ilustrado "hicieron que este espectáculo renovado apasionara al público español hasta el paroxismo" (idem: 151) y el torero se convirtió definitivamente en un verdadero héroe popular hasta la actualidad.

Era obligado para el viajero ir a los toros y quizá el mejor testimonio de lo que ocurría con esta experiencia sea el de Merimée:

Los extranjeros, que no entran en la plaza la primera vez sin cierto horror, y sólo a fin de cumplir en conciencia con los deberes del viajero, los extranjeros, digo, se apasionan pronto por las corridas de toros tanto como los propios españoles (Merimée 1988: 41).

Si el torero se convirtió en un verdadero héroe popular ya en el siglo XviII, y esta consideración la ha tenido hasta épocas recientes, el arquetipo de ese héroe se construyó propiamente en el siglo XIX y fue principalmente a través de la visión de los extranjeros y la reconstrucción literaria, novelesca, que hicieron. Por otro lado, la tauromaquia además de con el heroísmo, estaba relacionada con el amor y la mujer. Richard Ford (1963: 38) recoge en estos términos esa relación:

Arriesgar la vida como un verdadero caballero era siempre el camino más seguro para llegar al amor de las mujeres, que son las que más y mejor admiran esas cualidades, en las que se consideran más deficientes. Hudibras (p.1.c.3) ha aludido a ese poderoso filtro: 'Los corazones de las damas comenzaban a derretirse, / Humillados por los golpes, caían sus amantes; / Así los héroes españoles, con sus lanzas, / Herían a la vez los toros y el corazón de las damas' (González Troyano 1988: 111$)^{30}$.

Como advierte González Troyano, de los extranjeros fue Merimée quien supo sacar la mayor potencialidad literaria y dramática de la fiesta, también a él debemos la gran construcción del personaje de Carmen que necesariamente lleva a otro de los grandes atractivos de España para el

\footnotetext{
${ }^{30}$ Este autor estudia en el capítulo tercero el papel de los románticos extranjeros como desveladores de las posibilidades del género taurino en la literatura.
} 
viajero, la mujer ${ }^{31}$. Sobre la belleza - gracias en parte a esos ojos negros de mirada intensa- de la mujer española se llenaron páginas y páginas, pero también se ha escrito mucho sobre su gracia al llevar la mantilla y manejar el abanico, su pie pequeño como peana del esbelto talle, sus ágiles y provocativos movimientos que llegaban al paroxismo cuando bailaban el seductor y erótico bolero. Pero en el personaje de Carmen se funden los tipos femeninos más populares ${ }^{32}$, y que servían de solaz y disfrute al viajero con sólo contemplarlas: la maja, la gitana y la cigarrera. Aunque todas ellas fueron motivo de atracción turística, el caso de la cigarrera es quizá el más doloso: a estas mujeres explotadas, con jornadas laborables interminables y sueldos miserables, que por su situación se veían obligadas a trabajar y a ser madres a la vez en un ambiente contaminado por el ruido y la mala ventilación, insalubre y carente de toda higiene, se las iba a ver a la fábrica o a la salida cuando se encontraban con "sus hombres" como una actividad más del viaje. Así se podía disfrutar del colorido y la diversidad que presentaban ante los ojos centenares de féminas con sus hijos pequeños encerradas en grandes salas manipulando artesanalmente, con sus ágiles manos, el tabaco; percibir su carácter alegre y dicharachero, y dar testimonio de su exótica belleza ${ }^{33}$.

\section{LOS DIFÍCILES CAMINOS HISPANOS}

Estrechamente relacionados con estos tipos populares de mujeres se encontraban el contrabandista y el bandolero, en el fondo un mismo personaje con doble actividad, un héroe tipo Robin Hood dedicado a asaltar a los viajeros. De nuevo se constata que una de las razones de la falta de civilización en la España dieciochesca era la inseguridad de los caminos, los asaltos eran continuos y en ellos muchas veces se perdía la vida,

\footnotetext{
${ }^{31}$ Teniendo en cuenta que hasta mediados del siglo XIX no comienza la mujer a participar en los países más; desarrollados de Europa de la costumbre de viajar, dadas las condiciones que ofrecía España, el número de viajeras es pequeño. Se da la circunstancia de que las viajeras inglesas llegaron a España con posterioridad a la publicación de la guía de Ford, eso no quita para que asistieran a los toros e incluso se aventuraran a subir Sierra Morena como es el caso de Lady Louisa Tenison. En cuanto a las viajeras francesas, aunque cuando llegaron a España (entre 1847 y 1867) habían mejorado sustancialmente los medios de locomoción -el tendido ferroviario era ya amplio-, todas ellas decidieron recorrer la península "a la vieja usanza, es decir, en diligencia, a lomos de mulas o caballo" (Echeverría Pereda 1995: 94).

32 Sobre esta cuestión y el personaje literario cf., González Troyano (1991).

33 Sobre la representación de la cigarrera, Vega (1993: 163-165). Sobre las condiciones de trabajo, Capel Martínez (1998); y O’Connor (1998).
} 
para lo cual basta recordar las dos pinturas de Francisco de Goya sobre el tema. Se sabe que en los años finales del siglo xviII y comienzos del xIx el bandolerismo cobró gran intensidad debido al incremento del tráfico y al desarrollo del mercado. En las reales cédulas de 1802 y 1807 se reconoce que los caminos - sobre todo los más transitados- estaban infestados de bandoleros, los cuales cuando eran apresados, juzgados y ejecutados con la pena de horca, para amedrentamiento de los paisanos y espanto del viajero ilustrado, eran descuartizados y colgados en palos en todos los caminos, salvo los que iban a los sitios reales cercanos a Madrid. La situación no mejoró después de la guerra contra Napoleón, ya que los incipientes frutos de la política ilustrada en favor de la industria y el trabajo manual se frustraron y, como explicaba Edward Hawke Locker, "muchos españoles no volvieron ya a las pacíficas tareas del telar y del arado, sino que, familiarizados con el saqueo y la violencia, se convirtieron en contrabandistas y bandidos". Pero de nuevo lo que repelía al ilustrado se tornó, para el viajero romántico, en uno de los grandes atractivos de España: ser asaltado por un bandolero. De este modo resumía Theophile Gautier el viaje a España:

Un viaje por España es todavía empresa peligrosa y romántica; hay que contribuir con la persona, tener valor, paciencia y fuerza. A cada paso se arriesga la vida, y los menores inconvenientes con que se tropieza son las privaciones de todo género, la falta de las cosas más indispensables para la vida, el peligro de los caminos, verdaderamente impracticables para quienes no sean arrieros andaluces; un calor infernal, un sol capaz de derretir el cráneo; además, hay que enfrentarse con los facciosos, los ladrones y los posaderos, gente bribona, cuya honradez se acomoda al número de carabinas que lleva uno consigo. El peligro os rodea, os sigue, os precede; sólo oís cuchichear historias terribles y misteriosas. Ayer los bandoleros comieron en esta posada. Una caravana fue detenida y conducida al monte por los facinerosos, para pedir rescate. Palillos ${ }^{34}$ está emboscado en tal sitio, por donde ustedes tienen que pasar. Indudablemente, en todo esto existe mucha exageración; pero, por muy incrédulo que uno sea, no hay más remedio que convencerse de que hay algo de cierto, cuando en cada encrucijada se ven cruces de madera con inscripciones de este género: Aqui mataron a un hombre. - Aqui murió de mampairada ... [mano airada] (Gautier 1985: 234).

Hubo más de un viajero que adornó su relato con esta aventura, pero parece que fueron pocos los "afortunados" que recibieron la visita del

\footnotetext{
${ }^{34}$ Parece que este personaje tenía más de salteador que de guerrillero realista y actuaba sobre todo en los caminos de La Mancha. Al hablar de la inseguridad de los caminos hay que tener en cuenta que entre los años 1833 y 1849 se vivió en España bajo una situación de guerra permanente, debido al enfrentamiento entre los partidarịos de Isabel II y los de Carlos María Isidro, hija y hermano respectivamente de Fernando VII. La primera era apoyada por los liberales, el segundo por los partidarios del absolutismo monárquico del carlismo.
} 
bandolero. Entre ellos cabe citar a Alexander Slidell, llamado Mackenzie, quien fue testigo de un atraco en 1826 según relata en su libro $A$ Year in Spain. Entre los quejosos de no haber tenido esta experiencia se puede citar una larga nómina, pero quizá un ejemplo elocuente es el de Prosper Mérimée. En una carta fechada en noviembre de 1830 en Madrid -publicada en la Revue de Paris el 26 de agosto de 1832- escribía sobre los ladrones españoles y decía:

\begin{abstract}
Heme aquí de regreso en Madrid, después de haber recorrido durante varios meses, y en todas direcciones, Andalucía, esa tierra clásica de los ladrones, sin haber encontrado ninguno. Casi me da vergüenza. Me había preparado para un ataque de ladrones, no para defenderme, sino para conversar con ellos y preguntarles con gran cortesía acerca de su género de vida [...] Pero si no he visto ladrones, en cambio no he oído hablar de otra cosa. Los zagales, los venteros os cuentan historias lamentables de viajeros asesinados, de mujeres raptadas, a cada alto que se hace para cambiar de mulas. El suceso que cuentan siempre aconteció la víspera y en el trayecto que uno va a recorrer (Merimée 1988: 78-9).
\end{abstract}

Esto no significa que no hubiera asaltos, el número de bandoleros era creciente y, además, contaban con el favor popular. Adolphe Guéroult lo explicaba en estos términos:

el bandolerismo se extiende y se nutre de mil maneras: un soldado sin paga, el recluta amenazado con enrolarse, el individuo arruinado por la guerra, el pensionista de un convento, privado de su pan cotidiano; todo ello hace coger el fusil y marcharse a ganarse la vida en las rutas importantes. Pero esto, que en otro país no sería sino un inconveniente temporal, secundario y de competencia policial, aquí es una calamidad contagiosa que una guerra continuada puede convertir en azote, al favorecer su desarrollo así como la miseria, la impunidad y hasta la consideración, arraigada en el pueblo, por el oficio de ladrón (Guéroult 1838: 132-33).

La inseguridad crónica de los caminos no se acabará hasta mediado el siglo cuando la recién creada Guardia Civil en 1844 se despliegue por todo el territorio, entre cuyas misiones se contarán con el tiempo eliminar al salteador de caminos y velar por la seguridad de la circulación de las personas y mercancías, auxiliando a los vehículos y viajeros que se encontraban en problemas.

Con todos estos atractivos propios el viajero en España podía superar las dificultades, debidas principalmente al sistema del transporte y al alojamiento. Santos Madrazo en su excelente libro sobre el tema (Madrazo Madrazo 1991) ${ }^{35}$, ha realizado un estudio pormenorizado de estas cuestiones. Eran varios los sistemas empleados por los viajeros a comienzos del

35 Véase también (Madrazo 1984) y (Uriol Salcedo 1992). 
siglo XIX y que pervivirán hasta quedar sustituidos por el ferrocarril. Lo más incómodo, pero muy barato era "viajar por arrobas", es decir, el viajero era tratado como una carga y pagaba en función de su peso. Más cómodo, rápido y caro era viajar por la "posta a caballo", no obstante, este sistema se empleó poco para el tráfico de viajeros pero fue fundamental para el tráfico de noticias. La caballería fue una forma habitual para los desplazamientos. Había tres tipos de cabalgadura: caballo y mula para el trasporte de personas, y burro normalmente dedicado a los equipajes y mercancías. Era necesario contar con un criado y, por lo general, se preferían las mulas a los caballos ya que muchos caminos, sobre todo los del norte de España y de montaña, no eran adecuados para el caballo mientras las mulas se adaptaban mejor, eran más resistentes y seguras en su paso. La norma general era comprar el animal y contratar los servicios del mulero, pero más barato era unirse a la recua de arrieros, carreteros o caleseros - conocidos como los "ordinarios" porque seguían una ruta más o menos repetida y paraban en Madrid en calles y establecimientos fijos-, los cuales se encargaban del equipaje del viajero. Viajar solo no era recomendable por cuestiones de seguridad, y en ningún caso era aconsejable hacerlo andando ya que esto era propio de vagabundos y mendigos ${ }^{36}$, lógicamente por necesidad: el viajero se exponía al llegar a la población de turno a no ser bien recibido y ni siquiera poder entrar en las posadas (Borrow vivió esta desagradable experiencia al llegar a Astorga). Los mendigos acosaban a los viajeros nada más entrar en el país (Borrow 1996: 108) y se topaba con ellos en todos los núcleos urbanos; tanto es así que llegó a convertirse en un tipo característico, digno de ser descrito, dibujado y fotografiado.

Con una buena caballería se podía llegar a cualquier parte, pero no ocurría lo mismo si se viajaba en vehículos de rueda: los caminos de herradura era los que comunicaban toda la península, mientras que los de rueda se limitaron al sistema radial de comunicaciones de la capital. Este sistema radial se convirtió desde entonces en estructural (serán los ejes de comunicación postal y ferroviaria primero, automovilística después) y se desarrolló plenamente entre 1818 y 1855. Por el camino de Aragón

\footnotetext{
36 "Andando es como viajan los animales, que para eso tienen cuatro pies; los bípedos que siguen el ejemplo de los brutos, pronto se convencerán de que se rebajan a su nivel en más de un respecto. Además, como ningún español anda por gusto y nadie emprende una jornada a pie, sino los mendigos y vagabundos, no se comprende que se haga más que por absoluta necesidad. Por esta razón los peatones son mal recibidos y objeto de toda clase de sospechas, pues las autoridades españolas, juzgando a todos por sí mismas, siempre piensan lo peor de los extranjeros, considerándoles culpables mientras no se demuestre lo contrario" (Ford 1974: 100).
} 
y Cataluña se comunicaba Madrid con Zaragoza, Barcelona y Figueras donde terminaba; a su paso se atravesaban las ciudades de Alcalá de Henares, Guadalajara, Daroca, Lérida, Cervera y Gerona ${ }^{37}$. El camino de Andalucía iba de Madrid a Cádiz pasando por Antequera, Córdoba, Écija, Jerez y el Puerto de Santa María ${ }^{38}$. El camino de Extremadura pasaba por Badajoz y llegaba a Lisboa ${ }^{39}$. Finalmente el camino de Castilla iba por León hasta Galicia y Asturias ${ }^{40}$. De estas rutas principales partían los caminos secundarios, más estrechos y peores, apropiados para la caballería. De los caminos secundarios salían sendas y carriles que comunicaban con las poblaciones rurales, por lo general eran de tránsito aún más difícil y lento. Completaban la red viaria los caminos militares en raras ocasiones empleados por los viajeros porque la finalidad era el control del territorio y la circulación de las tropas - hay que recordar que España estaba en guerra.

La red transversal de comunicación entre ciudades periféricas quedó siempre desasistida - no llegó a completarse hasta el final de la centuria- lo que significaba que, por ejemplo, para viajar de Barcelona a Valencia era necesario pasar por Madrid. Como se puede entender, si con una buena mula se podía llegar a cualquier parte, no ocurría lo mismo con los vehículos de ruedas que se limitaban a circular por la red principal. El "coche de colleras" era el típico del país, antes de que existiera la diligencia. Aunque era incómodo, era sólido y podía marchar con el tiro de seis mulas, al galope. La "galera" se empleaba en los caminos donde no circulaba la diligencia; al ser un carromato sin muelles resultaba incómodo, pero era barato. El viajero podía alquilar un vehículo para su uso privado, había berlina, calesa, calesines, cabriolés, birlocho, landó, tartana, volantes, etc. Muchos de los viajeros disfrutaban viendo circular coches que hacía ya mucho tiempo habían desaparecido en sus países de origen, reforzando ese sentimiento de viaje al pasado:

\footnotetext{
${ }^{37}$ A partir de este camino principal se podía ir a Zuera y Huesca; Sacedón y Teruel; Valencia, Alicante y Murcia; éste a su vez iba por Cartagena, Lorca y Caravaca.

${ }^{38}$ De este camino salían los secundarios de Granada, Guadix, San Roque, Almería, Úbeda, Sevilla y Ronda. De este último arrancaban los caminos hacia San Roque, Gibraltar, Algeciras y Tarifa.

39 De él salían los de Jerez, Llerena, Zafra, Guadalupe, Trujillo, Badajoz, Cáceres, Coimbra, Alcántara, Coria, Gata, Escorial, Ávila y Plasencia.

${ }^{40}$ Por éste se iba a Segovia, Valladolid, Palencia, Santander (de éste salía el de Burgos y Peñaranda de Bracamonte), Ledesma, Ciudad Rodrigo, Coruña, Santiago (de aquí a Pontevedra, Tuy, Orense, Vigo y Bayona), Mondoñedo (Vivero y Ribadeo), Burgos (Orduña, Bilbao y Bermeo), Miranda de Ebro (Vitoria, Tolosa, Irún y Bayona), Santander, Pamplona, Ágreda y Estella.
} 
La civilización, en lo que se refiere a transportes, está en España aún a muy bajo nivel, a pesar de las infinitas revoluciones políticas. Excepto en algunas grandes ciudades, los risibles vehículos nos recuerdan aquellas caricaturas que tanto nos divirtieron en París en 1814 (Ford 1974: 73).

A partir de la década de los treinta la diligencia se convertirá en el coche por excelencia para viajar en España, sustituyendo al coche de colleras. La primera diligencia entró en funcionamiento en 1819, y en 1850 eran ocho empresas las que prestaban el servicio. Fue una auténtica revolución. Según fue ampliando su radio de acción fueron haciéndose más frecuentes y rápidas — con el tiempo apareció el transporte acelerado$\mathrm{y}$, algo fundamental, se fueron estableciendo los horarios y tarifas. Se desarrollaron también las líneas de cercanías en torno a Madrid, que tuvieron mucho éxito, con varios servicios diarios a El Escorial, Toledo, los Carabancheles, Aranjuez, El Pardo, Jadraque, Torrelaguna, Arganda, Getafe y Segovia. Viajar en diligencia era caro, aunque había distintos tipos de billete (hasta cinco categorías), si bien los precios fueron bajando en general a medida que se implantaba el ferrocarril.

Según se desarrollaba la red viaria y mejoraban los vehículos, también fueron mejorando y aumentando los locales destinados a atender al viajero: las posadas. Las continuas quejas de los viajeros sobre las malas condiciones, falta de comodidad, higiene y plagas de insectos eran reales pero es fácil explicar cómo se había llegado a ese nivel de deterioro del servicio: el posadero no era propietario, debía pagar rentas altas al señor o al concejo, y además tenía que limitarse a preparar los alimentos que traían los viajeros -quienes debían proveerse en el camino de lo necesario, algo incomprensible para el extranjero- para no entrar en competencia con los negocios locales de tabernas, bodegones, carnicerías, etc. Esto explica que en muchas posadas se diera preferencia a la atención de los animales - cuadras y zaguanes, con un elevado número de pesebres- en detrimento de los humanos - lugares de descanso y comedores-, llegándose en algunas de ellas a una proporción de una cama por cada cuarenta pesebres. Con la red de diligencias, la regularidad y afluencia de viajeros hizo que este panorama comenzara a cambiar: se recomienda dónde deben establecerse y se ponen los medios para que el viajero pueda encontrar lo necesario para su comodidad, aseo y una alimentación de calidad. En estos puntos fijos también se desarrolló el establecimiento de actividades relacionadas con el mantenimiento del vehículo: herreros, carroceros, guarnicioneros, etc. Pero los dos tipos españoles, que se sumarán al repertorio que recabará la atención del viajero, serán los que conducen la propia diligencia: el mayoral y el zagal —si bien ambos guiaban también el coche de colleras-. 
El "mayoral", además de ser el representante de la compañía, se ocupaba del cuidado y mantenimiento del vehículo, de la atención de las caballerías en las paradas y del alojamiento y seguridad de los viajeros, se le reconocía por el atuendo particular y pintoresco que llevaba. El "zagal" era su ayudante, un muchacho que se sentaba a su lado y no debía entrar en contacto con los pasajeros. Su función principal era hostigar con la voz y el látigo, desde el asiento o corriendo, a los animales, estando atento a cualquier contrariedad que pudiera surgir y procurando que los relevos de caballería se hicieran con rapidez.

La red viaria muestra regiones escasamente comunicadas entre sí. Los extranjeros en general prefirieron los medios de rueda para viajar y hacían un itinerario más o menos fijo en diligencia, quedando fuera del recorrido una buena parte del país. Solían entrar en España por Bayona, y pasando por Vitoria, Pancorbo y Burgos, llegaban a Madrid donde estaban una o dos semanas. Establecidos en la capital hacían excursiones a Toledo, El Pardo, Aranjuez, El Escorial, Segovia y Ávila. Continuaban viaje a Andalucía por Despeñaperros, dirigiéndose bien a Granada y Málaga, bien a Córdoba, Sevilla y Cádiz. Después marchaban a Levante: Murcia, Valencia y Barcelona. Por su parte Castilla la Vieja, una buena parte de Aragón, Galicia, León y Extremadura quedaban bastante al margen de estas rutas, y fueron poco frecuentadas. El interés creciente por el sur desarrolló un itinerario propio que tuvo éxito: tras desembarcar en Gibraltar se seguía la ruta de los contrabandistas por Ronda y Antequera hasta Granada, de allí se iba a Málaga de regreso a Gibraltar, o se acercaban a Sevilla.

\section{LA BÚSQUEDA DE LA DIFERENCIA: LA HUÍDA DE LA CIVILIZACIÓN}

Pero el verdadero viaje a España era aquél que estaba fuera de estos caminos trillados. Richard Ford lo recomienda continuamente a sus lectores. Como reconoce también Gautier, allí era donde no había llegado la civilización, donde se encontraba la verdadera España que a medida que se civilizaba perdía su identidad:

Durante los viajes, los españoles recobran su antigua originalidad y se despojan de toda imitación de lo extranjero; el carácter nacional reaparece por entero en esos convoyes que atraviesan las montañas, los cuales no deben de ofrecer gran diferencia con las caravanas en el desierto. Lo áspero de los caminos, apenas marcados; lo salvaje y grandioso de los lugares, el traje pintoresco de los arrieros, los arreos extraños de las mulas, los caballos y burros marchando en reata; todo ello os traslada a mil leguas de la civilización. El viaje se convierte en una cosa real, un acto del que formáis parte. En una diligencia, el hombre deja de ser hombre para convertirse en un objeto inerte, en un paquete que no se diferencia gran 
cosa de su maleta. Os trasladan de un lado a otro, y eso es todo. Lo mismo da quedarse en casa. Lo que constituye el placer del viajero es el obstáculo, la fatiga, hasta el peligro. ¿Qué encanto puede ofrecer una excursión cuando se tiene la seguridad de llegar, de encontrar caballos a punto, una cama blanda, una buena cena y todas las comodidades que disfruta uno en su casa? Una de las grandes desgracias de la vida moderna es que falta lo imprevisto, la ausencia de aventuras (Gautier 1985: 233-234).

\section{De este modo también lo expresaba Borrow:}

El día por demás caluroso y con mucha lentitud proseguimos la marcha a través de las llanuras de Castilla la Vieja. En todo lo perteneciente a España, la inmensidad y la sublimidad se asocian. Grandes son sus montañas y no menos grandes sus planicies, ilimitadas, al parecer; pero no como las uniformes e ininterrumpidas llanadas de las estepas rusas. El terreno presenta de continuo escabrosidades y desniveles; aquí, un barranco profundo o rambla, excavado por los torrentes invernales; más allá, una elevación, muchas veces fragosa e inculta, en cuya cima aparece un pueblecito aislado y solitario. ¡Cuánta melancolía por doquier; qué escasas las notas vivas, joviales! Aquí y allá se encuentra a veces algún labriego solitario trabajando la tierra; tierra sin límites, donde los olmos, las encinas y los fresnos son desconocidos; tierra sin verdor, sobre la que sólo el triste y desolado pino destaca su forma piramidal. ¿Y quién viaja por estas comarcas? Principalmente los arrieros y sus largas recuas de mulas, adornadas con campanillas de monótono tintineo. Vedlos, con sus rostros atezados, sus trajes pardos, sus sombrerotes gachos; ved a los arrieros, verdaderos señores de las rutas de España, más respetados en estos caminos polvorientos que los duques y los condes; vedlos: mal encarados, orgullosos, rara vez sociables, cuyas roncas voces se oyen en ocasiones desde una milla de distancia, ya excitando a los perezosos animales, ya entreteniendo la tristeza del camino con rudos y discordantes cantares (Borrow 1996: 246).

Como se ve, esos caminos secundarios eran una fuente inagotable de sensaciones y experiencias y daban la oportunidad de disfrutar del paisaje, otro importante motivo para viajar a España. En el exhaustivo análisis de Esther Ortas Durand sobre los viajeros ante el paisaje aragonés es fácil comprender la inquietud, los temores y el deleite que se podía sentir frente la diversidad de los paisajes españoles, diversidad debidamente difundida y aclamada por los autores citados, pero que ya fue advertida en otros parajes hispanos por viajeros anteriores ${ }^{41}$. Ahora bien, la revalo-

${ }^{41}$ Por ejemplo el norteamericano Ticknor "gusta de la ponderación de las excelencias paisajisticas de las vistas "beatifully and rich" con que le obsequian las costas mediterráneas, de la vista "of singular beauty and variety" de la Granja, de las "glorious prospects" y el "enchanting scenery" que exhibía Granada, de ese "romantic spot" de la sierra que ofrece una vista de Córdoba, de las aundisturbed solitudes of nature. que alberga Sierra Morena, o del pintoresquismo de ciertos enclaves peninsulares" (Ortas Durand 1999: 92). 
rización del paisaje español era también consecuencia del nuevo cambio de mentalidad de quien lo contemplaba. En el siglo xviII la belleza del paisaje iba intrínsecamente unida a la utilidad del mismo, al aprovechamiento económico, y a la presencia del hombre en su transformación. Ahí era donde se encontraba la belleza, la amenidad y el agrado para los viajeros, pero este tipo de paisaje era precisamente el que más escaseaba en España. En el siglo XIX se alteran por completo los parámetros para la valoración y el disfrute del paisaje, y los contrastes y la diversidad del medio natural español cobran un nuevo valor. Además el interés por los estudios geológicos y botánicos, el deseo de explorar las montañas y buscar parajes en estado "puro", sin contaminar por la civilización y el hombre, atrajeron a las cordilleras españolas —desde los Pirineos a Sierra Morena (Titos 1994) - a muchos viajeros. Estas experiencias eran difíciles de transmitir, en muchas ocasiones no hay palabras para describir lo que se contempla y no es posible incluso trasladarlo a una imagen, pero, a la vez, eran las que más acrecentaban el sentimiento aventurero -el drama de España, que diría Andersen ${ }^{42}$ - porque, cuanto más se alejaba el entorno del medio urbano, más desprotegido y vulnerable se sentía todo aquel que venía de la civilización:

Los Pirineos españoles ofrecen pocos atractivos a los aficionados a las comodidades de la ciudad; pero el paisaje, el aliciente de las excursiones, la geología y la botánica son verdaderamente alpinos y compensarán con creces a los que se atrevan a "pasar trabajos" viajando por ellos. El contraste que presenta la parte española, poco frecuentada, con la opuesta es notable. A pesar de ser ésta más abrupta y más castigada por la nieve, los muchos establecimientos de baños de los Pirineos franceses son muy frecuentados y están llenos de caminos, diligencias, hoteles, caseríos donde se puede hacer alto para comer, cicerones, borriquillos de alquiler, etc. Todo esto para los bobos de París que se pasan la vida decantando las excelencias de los verdes campos y de los belles horreurs; pero que no suelen alejarse mucho. En pocas partes se dará una prueba más evidente de falta de gusto y de amor a lo bello y elevado - dice Mr. Erskine Murray- que en los Pirineos franceses, donde la mayor parte desconoce en absoluto la belleza de sus montañas, las cuales han sido exploradas principalmente por ingleses (Ford 1974: 30).

Paisajes desérticos, monótonos, sublimes, grandiosos, horribles, espantosos, terribles, imponentes, pintorescos, románticos y salvajes podían

${ }^{42} \mathrm{Al}$ pasar por los Pirineos españoles escribe: "Un trozo de paisaje alpino, una colosal montaña nevada, se alzó ante nosotros; de súbito desparramó el sol naciente sus rayos sobre la blanca nieve, la cumbre se puso al rojo vivo, la montaña entera resplandecía $y$, según el sol avanzaba por el cielo y el fulgor de la nieve se apaga, se tiñeron de rojo, por cierto tiempo, la parte baja de la montaña y el valle recientemente sumido en sombras. Era un espectáculo sin par, una obertura en color del drama español que para nosotros comenzaba en aquellos momentos" (Andersen 1988: 15). 
encontrarse en toda Espana. Ante ellos se tenían los sentimientos de soledad, abandono, miedo, espanto, melancolía, confort.... Se podían, como ante las ruinas, tener ensoñaciones o sentir deseos de dibujar y pintar -en muchas ocasiones se caracteriza al paisaje principalmente según la pintura de un maestro (Ortas Durand 1999: 302-336)_. Esta actividad era connatural al viaje y, de hecho, ya en los manuales al uso del viajero ilustrado europeo se consideraba necesario contar con habilidades para el dibujo ya que reportaba momentos de solaz y disfrute, y permitía llevarse a casa recuerdos o anotaciones de interés. No obstante, en España no era tan fácil dedicarse a estos menesteres, la desconfianza sistemática de los paisanos y las sospechas que provocaban hizo que más de uno se las tuviera que ver con las autoridades y diera con sus huesos en la cárcel (George Sand 2000: 38).

Por supuesto que, a pesar de lo inefable de la visión, son muy numerosas las descripciones literarias. George Sand se vio en muchas ocasiones prisionera de la limitación de las palabras ${ }^{43}$, quizá esa dificultad y su deseo de atraparla hayan convertido esas descripciones y ensoñaciones en la parte más valiosa de su obra. La escritora encontró en Mallorca el paisaje alpestre, el paisaje exótico, el paisaje romántico, lo pintoresco y lo sublime, en suma el romanticismo materializado. Es éste un aspecto que cobra un valor especial en el viaje de Chopin y George Sand a Mallorca, donde la razón fundamental es la búsqueda intencionada de una alienación de la civilización. Tras esa declaración expresa de "viajo por viajar" sabiendo que "viajar es un placer por sí mismo", hay otra más profunda, la de la huida:

Todos cuando tenemos un poco de ocio y de dinero, viajamos, o más bien huimos, porque no se trata tanto de viajar como de partir, ¿me entiendes? ¿Quién de nosotros no tiene algún dolor del que se ha de distraer, o algún yugo que se ha de quitar de encima? [...] la mayor parte de nosotros viajamos en busca del misterio, del aislamiento, y por una especie de sombra que la compañía de nuestros semejantes proyecta sobre nuestras impresiones personales, sean dulces, sean penosas [...] cuando huimos del lugar de acción en busca del olvido y del reposo

43 "Mallorca es hoy para los pintores uno de los más bellos países de la tierra y uno de los más ignorados. Allí donde no se puede describir más que belleza pintoresca, la expresión literaria es tan pobre [...] Hacen falta los lápices y el buril para revelar a los aficionados a los viajes las grandezas y las gracias de la naturaleza [...] La naturaleza parece burlarse del artista [en Suiza]. En Mallorca, en cambio parece que lo espere y lo invite. Allí, la vegetación adopta formas altivas y extrañas; pero no despliega aquel lujo desordenado bajo el cual desaparecen a menudo las líneas del paisaje suizo. La cima del peñasco recorta sus contornos bien inmóviles sobre un cielo deslumbrante, la palmera se curva por sí misma sobre los precipicios sin que la brisa caprichosa descomponga la majestad de su cabellera" (George Sand 2000: 37-38). 
en algún pueblo de un avance más lento y de espíritu menos ardiente que nosotros, sufrimos allí unos males que no habíamos podido prever, y nos arrepentimos de haber dejado el presente por el pasado, los vivos por los muertos ${ }^{44}$.

La progresiva modernización de España se aceleró a partir de $1850 \mathrm{y}$, según avanzaba el proceso, el país se igualaba al resto de Europa. El 5 de octubre de 1853 escribía Merimée: "He encontrado El Escorial tan triste como lo había dejado hace unos veinte años, pero la civilización ha penetrado en él: se encuentran camas de hierro y chuletas; ya no hay ni una chinche, ni frailes" (Merimée 1988: 227-8). La civilización arrasaba también con el paisaje ${ }^{45}$ y, como escribía el poeta Gustavo Adolfo Bécquer, este enclave se había "mantenido oculto entre los pliegues de la montaña hasta que el pico de la civilización allanó las escabrosas pendientes, hizo volar las rocas hechas mil pedazos y los rails se tendieron sobre su pedregosa cuenca" (Bécquer 1995: II, 663).

Como se ve, también fueron los viajeros extranjeros los primeros en sentir con nostalgia la civilización del país: "Todo está cambiado en España, convertido en prosaico y francés. No se habla más que de ferrocarriles y de industria", escribía Merimée (1988: 320) desde Madrid el 11 de noviembre de 1859 . Pero, muy poco después comenzaron a dolerse los españoles de este proceso:

\begin{abstract}
No hay duda —escribía Bécquer en 1864-, el prosaico rasero de la civilización va igualándolo todo. Un irresistible y misterioso impulso tiende a unificar los pueblos con los pueblos, las provincias con las provincias, las naciones con las naciones, y quién sabe si las razas con las razas. A medida que la palabra vuela por los hilos telegráficos, que el ferrocarril se extiende, la industria se acrecienta y el espíritu cosmopolita de la civilización invade nuestro país, van desapareciendo de él sus rasgos característicos, sus costumbres inmemoriales, sus trajes pintorescos y sus rancias ideas. A la inflexible línea recta, sueño dorado de todas las poblaciones de alguna importancia, se sacrifican las caprichosas revueltas de nuestros barrios moriscos, tan llenos de carácter [...] De un retablo al que vivía unida una tradición no queda aquí más que el nombre, escrito en el azulejo de una bocacalle [...] Las ciudades, no cabiendo ya dentro de su antiguo perímetro, rompen el cinturón de fortaleza que las ciñe (Bécquer 1995: II, 407).
\end{abstract}

Quizás en un exceso de simplificación, podríamos decir que los valores se habían invertido: ahora eran los españoles los que reivindicaban

${ }^{44}$ La escritora francesa y su famoso amante tuvieron múltiples problemas con los paisanos, y su estancia en Mallorca resultó amarga. La razón fundamental fue la inadaptación de ella, a pesar de que su modo de vestir eran enteramente español, y el carácter introvertido de los mallorquines, que pronto se sintieron escandalizados ante la forma de vida de los extranjeros.

${ }^{45}$ Sobre la nueva experiencia del paisaje como consecuencia de la modernización cf., Vega (2003). 
su pasado, su historia, con nostalgia; por el contrario el turista venía cómodamente a disfrutar de la España tradicional, inventada como contraste dentro de la civilización: el caso paradigmático será Sevilla y la famosa Feria de Abril. La consecuencia fue la parodia y caricaturización del turista por un lado (Bécquer 1995: II, 372-373), y por otro la protesta fundada -irónica y dolorosa, como la escrita por Juan Valera en 1868 titulada "Sobre el concepto que hoy se forma de España" (Valera 1942: II, 17721786)—, contra esa nueva imagen estereotipada de España y los españoles que se había forjado entre los extranjeros, y del que todavía existen vestigios, sólo hay que acercarse a cualquier agencia de viajes para reconocerlos.

\section{BIBLIOGRAFÍA CITADA}

AlBerich, J. 1976. Del Támesis al Guadalquivir. Antología de viajeros ingleses en la Sevilla del siglo XIX. Sevilla: Universidad de Sevilla.

Álvarez BarRientos, J. 2001. "La civilización como modelo de vida en el Madrid del siglo xviII". Revista de Dialectología y Tradiciones Populares LVI,1: 147-162.

Álvarez de Colmenar, J. 1707. Les delices de l'Espagne et du Portugal où l'On voit une description exacte des Antiquites, des Provinces, des Montagnes, des Villes, des Rivieres, des Ports de Mer, des Forteresses, Eglises, Academies, Palais, Bainst, etc. De le Religion, des moeurs des babitants, de leur fêtes, et généralment de tout ce qu'il y a de plus considerable a remarquer. Leyden: Pierre Van der Aa.

Álvarez Miranda, P. 1992. Palabras e ideas: el léxico en la Ilustración temprana en España (1680-1760), Anejos del Boletín de la Real Academia Española, núm. LI. Madrid: Real Academia.

ANDERSEN, H.-C. 1988. Viaje por España. Madrid: Alianza.

BECKFORD, W. 1834. The Journal of - Londres: Richard Bentley.

BÉCQUER, G. A. 1995. Obras completas. Madrid: Turner.

BERGE. P. van de. 1701. Theatrum Hispaniae: exbibens Regni Urbes, Villas ac Vividaria magis illustria. Amsterdam.

Borrow, G. 1996. La Biblia en España. Madrid: Alianza. Ed. M. Azaña.

BOURGOING; J.-F. 1788. Nouveau voyage en Espagne ou Tableau de l'état actuel de cette monarchie; contenant les détails les plus récens sur la constitution politique, les tribunaux, l'Inquisition, les forces de terre $\mathcal{G}$ de mer, le commerce $\mathcal{E}$ les manufactures, pricipalement celles de soieries $\varepsilon$ de draps; sur les nouveaux établissemens, telles que la Banque de Saint-Charles, la Compagnie des Philippines, $E$ les autres institutions qui tendent à régénérer l'Espagne; enfin, sur les moeurs, la littérature, les spectacles, sur le dernier siège de Gibraltar $\&$ le voyage de Moseigneur Comte d'Artois; ouvrage dans lequel on a présenté avec impartialité tout ce qu'on peut dire de plus neuf, de plus avéré $\mathcal{E}$ de plus intéressant sur l'Espagne, depuis 1782 jusqu'à présent; avec une carte eluminée, des plans $\varepsilon$ des figures en taille-douce. París: Regnault, 3 vols.

BozAL, V. 1989. "La estampa popular en el siglo XVII", en AA. VV., El grabado en España (siglos XV-XVII), Summa Artis, vol. XXXI. Madrid: Espasa Calpe. 
CAPEl MARTíneZ, R.-M. 1998. "Life an Work in the Tobacco Factories: Female Industrial Workers in the Early Twentieth Century", en V.-L. Enders and P. B. Radcliff (eds.), Constructing Spanish Womanhood. Female Identity in Modern Spain. Nueva York: State University of New York Press.

CARRETE, J. 1989. "El grabado en el siglo XviII. Triunfo de la España Ilustrada", en AA.VV., El grabado en España (siglos XV-XVII), Summa Artis, vol. XXXI. Madrid: Espasa Calpe.

CASANOVA, G. 1982. Memorias. Madrid: Aguilar.

Cl.ARK, W.-G. 1850. Gazpacho; or Summer Months in Spain. Londres: J. W. Parker.

DAVILlieR, Ch. 1984. Viaje por España. Madrid: Adalia.

DEACON, P. 1996. "En busca de nuevas sensibilidades: el proceso civilizador en la cultura española del siglo xvir", en El mundo bispánico en el siglo de las Luces, Actas del Coloquio Internacional "Unidad y diversidad en el mundo bispánico el siglo XVII": 53-72. Madrid: Ed. Complutense/Sociedad Española de Estudios del siglo XVIII.

ECHEVERría Pereda, E. 1995. Andalucía y las viajeras francesas en el siglo XIX. Málaga: Universidad de Málaga.

FiSCHER, C.-A. 1799. Reise von Amsterdam über Madrid und Cadiz nach Genua in den Jabren 1797 und 1798, nebst einem Anbage über das Reisen in Spanien. Berlín: Johann Friedrich Unger.

FONTANELlA, L. y G. KURTZ. 1996. Charles Clifford fotógrafo de la España de Isabel II. Madrid: Ministerio de Cultura.

FORD, R. 1963. La fiesta de toros. Madrid: Unión de Bibliófilos Taurinos

- 1974. Las cosas de España. Madrid: Ediciones Turner.

FREIXA, C. 1993. Los ingleses y el arte de viajar. Barcelona: Ediciones del Serbal.

GarCía CárCel, R. 2003. Felipe $V y$ los españoles. Madrid: Debolsillo.

García Felguera, M. S. 2001. "Niños afortunados", en Niños de Murillo. Madrid: Museo del Prado.

GAUTIER, T. 1981. Voyage en Espagne. París: Flammarion.

-. 1985. Viaje por España. Barcelona: Taifa.

GEORGE SAND. 2000. Un invierno en Mallorca. Palma de Mallorca: José J. Oñaleta, Editor.

GIMÉNEZ CRUZ, A. 2004. La España pintoresca de David Roberts. El viaje y los grabados del pintor. Málaga: Universidad de Málaga.

GonZÁlez Troyano, A. 1988. El torero béroe literario. Madrid: Espasa Calpe.

- 1991. La desventura de Carmen, Madrid: Espasa Calpe.

GuÉROULT, A. 1838. Lettres sur l'Espagne. París: Louis Desessart.

HielsCher, K. 1921. La España incógnita. Barcelona: E. Canura (ed. facsímil Madrid, Agualarga, 2000).

INGLIS, H.-D. 1831. Spain in 1830. Londres: Whittaker, Treacher \& Co.

JARDine, A. 2001. Cartas de España. Alicante: Publicaciones de la Universidad de Alicante. Ed. de J.-F. Pérez Berenguel.

LABORDE, A.-L.-J. 1806-20. Voyage pittoresque et historique de l'Espagne. París: Imprimerie de Pierre Didot l'Ainé.

-. 1807. Viage pintoresco e histórico de España, por D. Alexandro de Laborde y una Sociedad de Literatos y Artistas de Madrid, dedicado al Serenísimo Señor Príncipe de la Paz Generalísimo Almirante de España e Indias, dado a luz por D. Antonio Bondeville, pintor de Cámara con privilegio del Rey N. S. Madrid: Imprenta Real.

LOCKER, E.-H. 1824. Views in Spain. Londres: John Murray. 
MADRAZO MADRAZO, S. 1984. El sistema de comunicaciones en España 1750-1850. Madrid: Turner, 2 vols.

-. 1988. "El mito de los caminos reales de Carlos III", en Equipo Madrid de Estudios Históricos, Carlos III, Madrid y la Ilustración. Contradicciones de un proyecto reformista. Madrid: Editorial siglo XXI.

- 1991. La Edad de Oro de las diligencias. Madrid y el tráfico de viajeros en España antes del ferrocarril. Madrid: Nerea.

MarTínez-Novillo, A. 2002. "Los toros en la España del siglo XviII", en C. García Sáiz (coord.), La España del siglo XVIII y el sueño de la razón. São Paulo: Fundación Arte Viva.

MERIMÉ, P. 1988. Viaje de España. Madrid: Aguilar.

MESTRE, A. 1983. "La imagen de España en el siglo XVIII: apologistas, críticos y detractores". Arbor 449: 49-73.

MEUNIER, L. 1665. Veuë du Palais Jardins, et Fontaine Darangouesse, Maison de plaisance du Roy d'Espagne, lieu tres curiex pour la grande abondance de ses Eaux et pour la grande quantité des figures de Bronze et de Marbre. París.

O'CONNOR, D.-J. 1998. "Representatión of Women Workers: Tobacco Strikers in the 1890s", en V.-L. Enders and P. B. Radcliff (eds.), Constructing Spanish Womanhood. Female Identity in Modern Spain. Nueva York: State University of New York Press.

ORTAS DURAND, E. 1999. Viajeros ante el Paisaje Aragonés (1759-1850). Zaragoza: Institución "Fernando El Católico".

PARDO, A. 1989. La visión del arte español en los viajeros franceses del siglo XIX. Valladolid: Universidad de Valladolid.

PARDO, J. 1966. Un inglés en la España de Godoy (Cartas españolas). Madrid: Taurus.

PINO, F. y ROMERO DE TEJADA, P. 1996. "Unidad y diversidad cultural en España, según los viajeros ilustrados", en El mundo bispánico en el siglo de las Luces, Actas del Coloquio Internacional "Unidad y diversidad en el mundo bispánico del siglo XVIII": 1065-1075. Madrid: Ed. Complutense/Sociedad Española de Estudios del siglo XVIII.

Planas, M. 2000. "Cronología del viaje de George Sand y Chopin y sus antecedentes a la luz de sus escritos autobiográficos y otros escritos contemporáneos", en George Sand, Un invierno en Mallorca. Palma de Mallorca: José J. Oñaleta, Editor.

PONZ, A. 1947. Viaje por España. Madrid: Aguilar.

PORTús, J. 1994. Museo del Prado. Memoria escrita 1849-1994. Madrid: Ministerio de Cultura.

Requejo, T. 1990. El palacio encantado. La Alhambra en el arte británico. Madrid: Taurus.

RODRíGUEZ DE LA FLOR, F. 1990. El gran libro de las Batuecas. Madrid: Tecnos.

RUBIO, J. 1992. "El viaje artístico-literario: una modalidad literaria romántica", Studies in Spanish Literature 1750-1915. Romance Quarterly 39,1: 23-31.

SwINBURNE, H. 1779. Travels through Spain in the Years 1775 and 1776, in which Several Monuments of Roman and Moorish Architecture are Illustrated by Accurate Drawings taken on the Spot. Londres: P. Elmsly.

TiCKNOR, G. 1913. Travels in Spain. Toronto: University of Toronto. Ed. G.-T. Northup. Titos, M. 1994. "Viajeros románticos en Sierra Nevada", El Gnomo 3: 111-127.

URIOl SAlCEDO, J.-I. 1992. Historia de los caminos de España, vol. II: Siglos XIX y XX. Madrid: Colegio de Ingenieros de Caminos, Canales y Puertos.

VALERA, J. 1942. Obras completas. Madrid: Aguilar. 
VAUGHAN, Ch.-R. 1809. Narrative of the Siege of Zaragoza. Londres: James Ridgway. VEGA, J. 1993. "Del grabado a la reproducción fotográfica: imágenes de Sevilla", en AA.VV., Iconografía de Sevilla, 1869-1936. Sevilla: Focus.

— . 2002. "El traje del pueblo, Ortiz Echagüe y el simulacro de España", en José Ortiz Echagüe en las colecciones del Museo Nacional de Antropología. Madrid: Ministerio de Educación, Cultura y Deporte.

- 2003. "El excursionista Carlos de Haes y la creación del paisaje moderno español", en Discutir el canon. Tradiciones y valores en crisis. Buenos Aires: CAIA.

VV.AA. 1981. Imagen romántica de España, Madrid, Ministerio de Cultura, 2 vols.

-. 1987. "Guía de los puentes de España". Revista del Ministerio de Obras Públicas y Urbanismo 345 , monográfico.

—. 1997. "Viajeros del XIX". Aportes. Revista de Historia Contemporánea 34,2, monográfico. 